\title{
Scrutinizing the Heavens, Measuring the Earth: Joseph Liesganig's Contribution to the Mapping of the Habsburg Lands in the Eighteenth Century
}

\author{
Madalina Valeria Veres \\ Postdoctoral Fellow, American Philosophical Society \\ madalina_veres@yahoo.com
}

\begin{abstract}
The Viennese Jesuit Joseph Liesganig made a significant contribution to the transformation of Habsburg mapmaking into a "scientific" enterprise before the dissolution of the Jesuit order. Liesganig's work began at the Vienna University Observatory as part of Empress Maria Theresa's and Chancellor Kaunitz's effort to build a network of scientific centers within the Habsburg lands. His 1769 field journal from his measurement of a meridian arc in the Hungarian plain and the resulting map disclose details about the personnel working with Liesganig, the instruments they used and their methodology. Although Liesganig failed to convince Maria Theresa to connect geodetic and astronomical measurements when mapping the Habsburg territories, Liesganig's 1769 instructions on how to represent large territories on a map based on mathematical principles shaped Maria Theresa's decision to commission a general survey of Lower Austria based on this method. These ties to court-sponsored science suggest why Habsburg monarchs only reluctantly implemented the papal directive to dissolve the Jesuit order in 1773. The Habsburgs continued to employ ex-Jesuits in their lands because of the important functions figures like Liesganig fulfilled in the domain of scientific development and cartography.
\end{abstract}

\section{Keywords}

Jesuit cartography - Jesuit science - Habsburg empire - César-François Cassini de Thury - Joseph Liesganig - Empress Maria Theresa - Vienna - Lviv - Austria - Hungary

(C) MADALINA VALERIA VERES, 2019 | DOI:10.1163/22141332-00601007

This is an open access article distributed under the terms of the prevailing CC-BY-NC license at the time of publication. 


\section{Introduction}

On the morning of May 18, 1761, César-François Cassini de Thury (1714-84), one of the most famous French astronomers and mapmakers of his time, arrived in Vienna. During his scientific mission to the Habsburg capital, he met the imperial couple, Maria Theresa (r.1740-8o) and Franz Stephan (r.1754-65), observed the transit of Venus in the company of future emperor Joseph II (r.17659o) and extended the Habsburg-Bourbon diplomatic alliance to the scientific sphere by working on a cartographic project with the Director of the Jesuit Observatory, Father Joseph Liesganig (1719-99). Cassini de Thury's fame due to his leading role in mapping France now greatly overshadows Liesganig's cartographic contributions, but their encounter tells a different story. In Cassini's own account, published in 1765 , he perceived the work in Vienna with Liesganig as a project done by equals. ${ }^{1}$

Although Vienna lacked an Academy of Sciences during the reigns of Maria Theresa and Joseph II, this was not symptomatic of a disinterest in promoting scientific initiatives. ${ }^{2}$ A more fruitful approach than focusing on identifying a counterpart in the Habsburg lands to the Royal Society in London or the Academy of Sciences in Paris is to examine where and how a Habsburg scientific discourse developed. In the case of cartography, individuals belonging to the Jesuit order, such as Liesganig, took active roles in institutionalizing expert knowledge, contributing to the rise of a new epistemology of mapmaking centered on the production of "scientific" maps.

Before Cassini de Thury's arrival in Vienna, Liesganig had already participated in the French Academy's global Geodesic Mission by measuring a basis of four thousand toises in the area of Vienna with an iron toise sent from Paris by Charles Marie de la Condamine (1701-74) and Nicolas-Louis de la Caille $(1713-62) .^{3}$ These two Frenchmen had been leading figures in the major

1 César-François Cassini de Thury, Relation de deux Voyages faits en Allemagne par ordre du Roi (Paris: Nyon, 1765), x-xi. For a detailed account of Cassini's map of France see Monique Pelletier, La carte de Cassini: L'extraordinaire aventure de la carte de France (Paris: Presses de l'école nationale des ponts et chaussées, 1990).

2 Joseph Feil discusses in detail the attempts to found an Academy of Sciences during Maria Theresa in Joseph Feil, Versuche zur Gründung einer Akademie der Wissenschaften unter Maria Theresia (Vienna: C. Gerold's Sohn, 1860).

3 Joseph Liesganig, Dimensio graduum meridiani Viennensis et Hungarici (Vienna: Augustinum Bernardi, 1770), 1-2. See Sven Widmalm, "Accuracy, Rhetoric, and Technology: The Paris-Greenwich Triangulation, 1784-88," in The Quantifying Spirit in the Eighteenth Century, ed. Tore Frangsmyr, J. L. Heilbron and Robin E. Rider (Berkeley: University of California Press 1990), 179-207, here 182; Ernst Bernleithner, "Oesterreichs Kartographie zur Zeit des Grafen Ferraris," in La Cartographie au XVIII siècle et l'oeuvre du Comte de Ferraris (1726-1814): 
scientific enterprises of the age: measuring arcs of meridian to establish the shape of the Earth and observing astronomical phenomena, such as the transit of Venus, to calculate the distance from the Sun to the Earth. ${ }^{4}$ As director of the Jesuit Observatory in Vienna from 1754, Liesganig actively participated in both projects. Shortly after the arrival of Cassini de Thury to the Habsburg lands, Liesganig showed him the best existing map of the area surrounding Vienna and revealed a plethora of faults. ${ }^{5}$ This was part of Liesganig's local advocacy for the necessity of building a triangulation network for the area around Vienna in order to improve the accuracy of existing maps. But where Cassini's printed maps and travel accounts circulated widely in print form, with the help of the French Academy, many of Liesganig's scientific writings and maps remained in manuscript. The Habsburgs' penchant for cartographic censorship and their reluctance to implement Liesganig's mapmaking methodologies for all their lands have made it hard to see his broader contributions. ${ }^{6}$

It has been well-established that Jesuits through their networks played a global role in the development of eighteenth-century science. ${ }^{7}$ Historians such as Luke Clossey have argued that "the missions of the Society of Jesus were the globalizing institution par excellence." 8 By the middle of the eighteenth century, the Society's scientific activity, as expressed through their teaching, their correspondence and their publications, worked in tandem with much of the

Colloque International Spa 8-11 Sept 1976 (Brussels: Crédit Communal de Belgique, 1978): 129-49, here 140.

4 For more information about La Caille's and La Condamine's scientific work see Ian S. Glass, Nicolas-Louis De La Caille: Astronomer and Geodesist (Oxford: Oxford University Press, 2013); Neil Safier, Measuring the New World: Enlightenment Science and South America (Chicago: University of Chicago Press, 2008).

5 Cassini de Thury, Relation de deux Voyages, xi.

6 Jan Mokre, "Geheimhaltung, Spionage und Kartenverfälschung: Aspekte des Verhältnisses zwischen Militär und Kartographie zur Zeit Maria Theresias," in Aspekte der Kartographie im Wandel der Zeit: Festschrift für Ingrid Kretschmer, ed. Wolfgang Kainz, Karel Kriz, and Andreas Riedl (Vienna: Institut für Geographie und Regionalforschung der Universität Wien, Kartographie und Geoinformation, 2004), 86-92.

7 See for example Daniela Bleichmar et al., eds., Science in the Spanish and Portuguese Empires 1500-180o (Stanford: Stanford University Press, 2009); Luis Millones Figueroa and Domingo Ledezma, eds., El saber de los jesuitas: Historias naturales y el Nuevo Mundo (Madrid: Iberoamericana, 2005); Florence Hsia, Sojourners in a Strange Land:Jesuits and Their Scientific Missions in Late Imperial China (Chicago: University of Chicago Press, 2009); Mario Cams, Companions in Geography: East-West Collaboration in the Mapping of Qing China (c.1685-1735) (Leiden: Brill, 2017).

8 Luke Clossey, Salvation and Globalization in the Early Jesuit Missions (Cambridge: Cambridge University Press, 2008), 257. 
scientific research of the time. ${ }^{9}$ This was especially true in the the Habsburg lands, where Roger Boscovich (1711-87), Maximilian Hell (1720-92) and Joseph Liesganig, all members of the Jesuit order, developed impressive scientific centers at the observatories in Vienna and Milan..$^{10}$

As a result, in contrast to most European states that had abolished the Jesuit order in the 1760 s, the Habsburg monarchs waited until 1773 and only reluctantly implemented the papal directive that year. Maria Theresa slowly reduced the Society's control over universities and censorship, but she continued to provide pensions and employment for ex-Jesuits working in the Habsburg lands. ${ }^{11}$ Liesganig's career is a case in point. Since $1755^{-56}$, Joseph Liesganig had been the director of the Jesuit Observatory in Vienna, but in 1772, shortly before the dissolution of the Jesuit order, Maria Theresa sent him to the eastern lands of Galicia, the newest Habsburg annexation. During the following decades, Liesganig prepared maps and a cadastral survey of this region, and continued his astronomical observations at the Observatory in Lviv. ${ }^{12}$

Liesganig in particular contributed to the effort to transforming mapmaking into an imperial science before 1773 . The Habsburgs' optimism in the power

Mordechai Feingold, "Jesuits: Savants," in Jesuit Science and the Republic of Letters, ed. Mordechai Feingold (Cambridge, MA: MIT Press, 2003), 23-38. See also John W. O'Malley, S.J., et al., eds., The Jesuits: Cultures, Sciences and the Arts 1540-1773 (Toronto: University of Toronto Press, 1999-2006).

10 Rita Tolomeo, Ruggiero Giuseppe Boscovich: Lettere per una storia della scienza (1763-1786) (Rome: Accademia Nazionale delle Scienze, 1991); Lancelot Law Whyte, ed., Roger Joseph Boscovich, S.J., F.R.S., 1711-1787: Studies of his Life and Work on the 25oth Anniversary of His Birth (London: Allen \& Unwin, 1961); Per Pippin Aspaas, "Maximilianus Hell (1720-1792) and the Eighteenth-Century Transits of Venus: A Study of Jesuit Science in Nordic and Central European Contexts" (PhD diss., University of Tromsø, 2012); László Kontler, “The Uses of Knowledge and the Symbolic Map of the Enlightened Monarchy of the Habsburgs: Maximilian Hell as Imperial and Royal Astronomer (1755-1792)," in Negotiating Knowledge in Early Modern Empires: A Decentered View, ed. László Kontler et al. (New York: Palgrave Macmillan, 2014), 79-105; Gerhard Geissl, Joseph Liesganig: Die Wiener Meridianmessung und seine Arbeiten im Gebiet von Wiener Neustadt (Wiener Neustadt: Verein Museum und Archiv für Arbeit und Industrie im Viertel unter dem Wienerwald, 2001).

11 Derek Beales, "Maria Theresa, Joseph II and the Suppression of the Jesuits," in Enlightenment and Reform in Eighteenth-Century Europe, ed. Derek Beales (London: I. B. Tauris \& Co., 2011), 207-26. Franz Szabo, Kaunitz and Enlightened Absolutism, 1753-1780 (Cambridge: Cambridge University Press, 1994), 244-45.

12 Stepan Apunevych et al., "First Astronomical Observatory in Lviv," Kinematics and Physics of Celestial Bodies 27, no. 5 (2011): 265-72; Geissl, Joseph Liesganig, 8; Thomas Posch et al., "Austrian-Hungarian Astronomical Observatories Run by the Society of Jesus at the Time of the 18th-Century Venus Transits," The Journal of Astronomical Data 19, no. 1 (2013): 121-30, here 122 . 
of maps to represent territory in an accurate manner and thus guide imperial military strategy and reforms relied on the activity of scientists like Liesganig. Armed with quadrant, plane table and his trained body, he performed data collection required for the production of what officers, civilian bureaucrats and statesmen considered more accurate maps.

\section{The Cassini-Liesganig Collaboration}

Historians of cartography and astronomy often mention the meeting between Cassini de Thury and Liesganig in Vienna and the work they did jointly in 1761 as an important result of the newly signed Habsburg-Bourbon's alliance (1756) and as a turning point in the history of Habsburg cartography. ${ }^{13}$ However, the impact of Cassini de Thury's visit to Vienna on Liesganig's career and approach to surveying should not be overestimated. In July 1759, Liesganig had already started surveying an arc of meridian between Vienna and Brunn with support from Maria Theresa and as a result of Roger Boscovich's suggestion. From the start, Liesganig had envisioned his survey as a continuation of the toise work of La Condamine in Peru, Boscovich in the papal states, and de la Caille at the Cape of Good Hope. Liesganig's dedication to contributing to the quest of identifying the shape of the Earth and his admiration of the French Academy of Sciences' methodology were thus merely reaffirmed after Cassini de Thury's journey to Vienna in 1761 .

In addition to observing together the transit of Venus, the Cassini-Liesganig collaboration included the construction of a triangulation network for the area surrounding Vienna, as illustrated on the "Map of Triangles used to determine the position of more sites in the area of Vienna"14 (Figure 6.1). Centered on Vienna, the map shows not only the meridian and parallel passing through this city, but also the perpendicular to the meridian of Paris. In this way the map symbolically connected the Habsburg and Bourbon domains. In the bottom left corner the scientists listed distances from twenty-three settlements to the meridian and parallel passing through Vienna. The top corners of the map display the imperial palaces at Schönbrunn and Laxenburg, as seen in Figure 6.2. The presence of these imperial residences reminded the viewer that the Habsburg patronage was what made this project possible.

13 Johannes Dörflinger, Die Österreichische Kartographie im 18. und zu Beginn des 19. Jahrhunderts 1 (Vienna: Österreichischen Akademie der Wissenschaften, 1984), 61-62.

14 "Carte des Triangles qui ont servis à déterminer la position de plusieurs lieux aux environs de Vienne," Österreichische Nationalbibliothek (ÖNB), Kartensammlung, AB 7 B 1. 


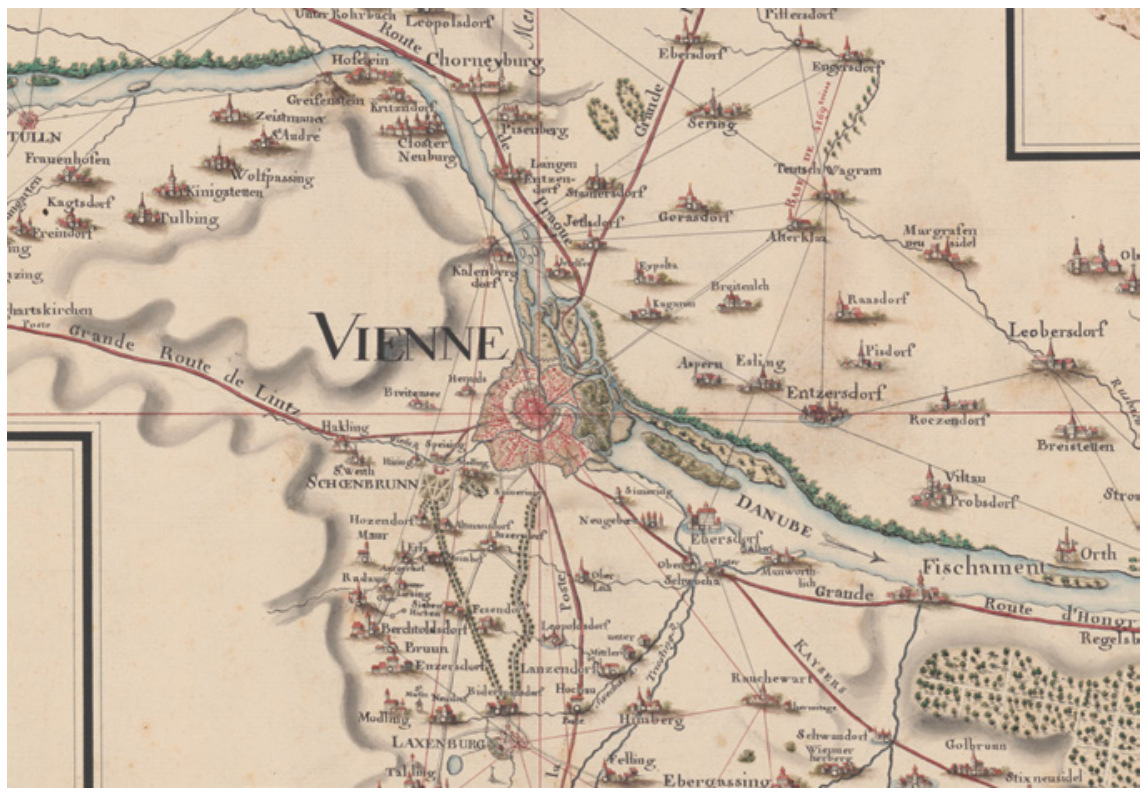

FIGURE 6.1 Vienna and its surroundings from Jean Baptiste d'Avrange's Carte des Triangles qui ont servis à déterminer la position de plusieurs lieux aux environs de Vienne [Map of Triangles used to determine the position of several sites in the area of Vienna] $(1761)$ ÖSTERREICHISCHE NATIONALBIBLIOTHEK (ÖNB), KARTENSAMMLUNG, АВ 7 B 1

During his time directly working with Cassini de Thury, Liesganig learned more about the methodology on which the Academy in Paris based the construction of the Map of France. Indeed, in 1762, shortly after Cassini de Thury's departure, Liesganig surveyed the area between Sobieschiz, close to Brunn in Moravia and Varasdin in Croatia, and measured two bases of around twelve kilometers each: Wiener Neustadt-Neukirchen and Seyring-RaasdorfGlinzendorf. Some of the students attending the courses at the Engineering Academy participated in the survey operations at Kahlenberg close to Vienna and learned from Liesganig the mechanics of such measurements. In the end, he managed to survey three degrees on the Vienna meridian. ${ }^{15}$ The measurement of meridian degrees and the training of military engineers in the art of

15 Bernleithner, "Oesterreichs Kartographie zur Zeit des Grafen Ferraris," 140-41; Dörflinger, Die Österreichische Kartographie im 18. und zu Beginn des 19. Jahrhunderts, 61-62; Geissl, Joseph Liesganig, 13-20. 


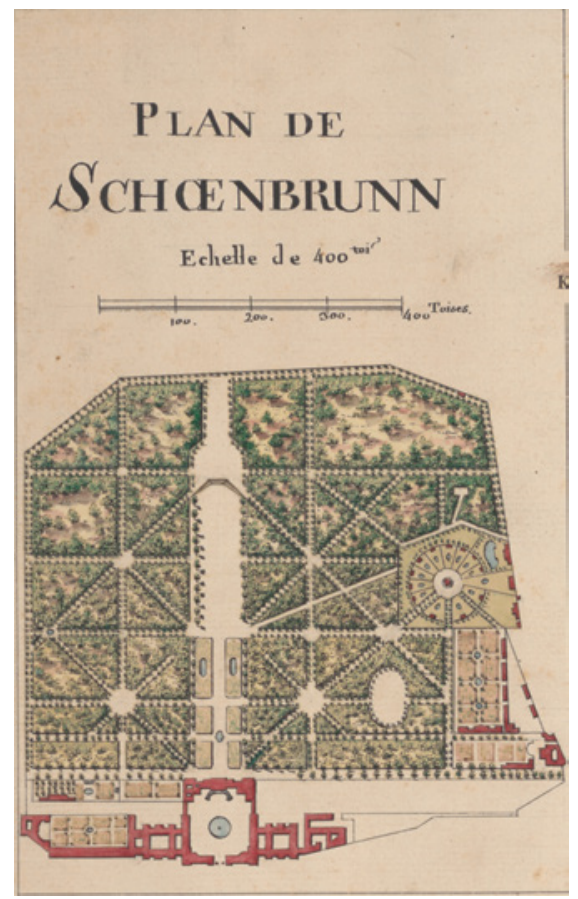

FIGURES 6.2A AND 6.2B

Schönbrunn and Laxenburg from Jean Baptiste d'Avrange's Carte des Triangles qui ont servis à déterminer la position de plusieurs lieux aux environs de Vienne, [Map of Triangles used to determine the position of several sites in the area of Vienna] (1761) ÖSTERREICHISCHE NATIONALBIBLIOTHEK (ÖNB), KARTENSAMMLUNG, AB 7 B 1

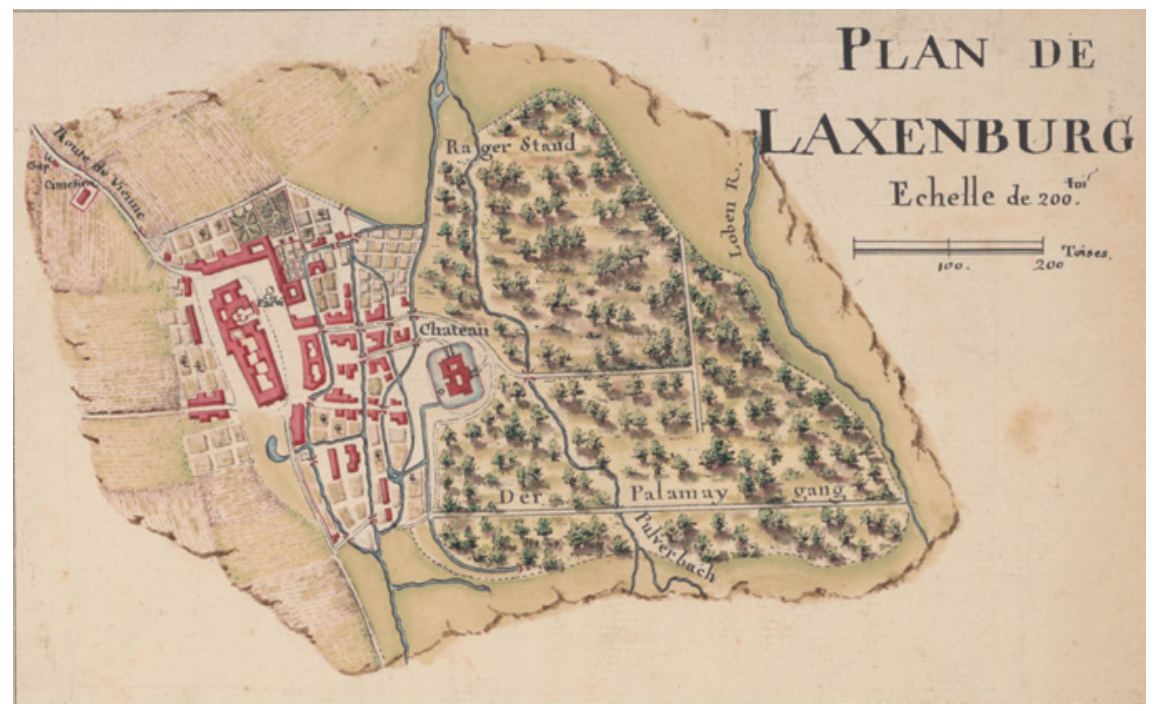


geodetic measurements could have been meant to serve as preparatory steps in ordering a survey of the Habsburg monarchy based on the French model.

This is exactly how Cassini de Thury had conceptualized his work in Vienna. On June 21, 1763, he submitted to Maria Theresa a narrative of his 1761 travels through the German lands as a sign of gratitude for the empress's "protection for the Sciences" and offered his services to improve the maps of all her empire. ${ }^{16}$ However, by the time the empress actually ordered the first military survey of her lands in 1763 , she had become aware of Cassini's slow pace in surveying French territories and instead commissioned the general quartermaster's staff of her empire to implement this project. ${ }^{17}$

\section{Liesganig's Scientific Expedition to Hungary}

Even though Cassini's map of France served as a cautionary tale for the first military mapping of the Habsburg monarchy, Maria Theresa remained receptive to the scientific principles guiding the French enterprise and continued to support Lieganig's work. On July 15, 1769, Liesganig proposed to Maria Theresa another meridian arc measurement in the Hungarian plain, in the neighboring area of Szeged. In his effort to convince the empress of the importance of such a venture, he mentioned how scientists from France, England and Italy all waited for this new measurement as a crucial step in establishing the true shape of the earth. He insisted that his work in Hungary would also contribute to the improvement of geographical knowledge about the Habsburg province. In exchange for imperial patronage, the astronomer offered to take with him a military engineer and train him in the French mapmaking technique. ${ }^{18}$ Maria Theresa gave Liesganig one thousand guldens for this expedition with a condition: he had to prepare a short memoir describing a method to represent large territories on a map based on true mathematical principles (wahren mathematischen Grundsätzen) ${ }^{19}$ Liesganig's journal of the expedition to Hungary and the memoir to Maria Theresa describing how to map large territories reveal the scientific principles he promoted in the field of mapmaking.

16 Vienna, Haus-, Hof-und Staatsarchiv (HHStA), Staatskanzlei (StK), Wissenschaft, Kunst und Literatur (WKL), box 5, folder Cassini de Thury und P. Luskanik(?), folio 2.

17 The work on the Map of France occurred between 1747 and 1788. The map was far from being finalized when the French Revolution erupted. Konvitz, Cartography in France, 21-31.

18 HHStA StK, Vortrage, box 104, folder $1,41^{\mathrm{r}-\mathrm{v}}$.

19 Ibid., 39; HHStA StK, WKL, box 5, folder Liesganig, P. 
Liesganig started his expedition on August 7, 1769 and took with him three assistants: the engineer-lieutenant Leopold Unterberger, the sapper lieutenant Hippolytus Verité, and another Jesuit, the mechanic Joseph Rämspöck. ${ }^{20}$ With the exception of Verité, who followed the team a couple of days later, they all travelled from Vienna to Buda on the Danube. Liesganig transformed the boat he travelled on into a site for scientific experiments, using a compass to record the accurate directions of the flow of the river. Unsuccessful in these attempts, he blamed the failure on the unreliable flow of the water and the quality of the shores. He also argued that only a geometrical survey could determine the exact trajectory of the Danube. In this case, having a trained scientist perform the observations was as important as using the proper methodology and instruments. The rise of the scientific expert is typical for what came to be seen in the eighteenth century as the basis for correct maps: figures and tables synthesizing the result of astronomic and geometric measurements replacing narrative tales and geographic descriptions as the raw data from which a map was built. $^{21}$

After a brief stay in Buda to make all the necessary arrangements for their trip, Liesganig and Unterberger resumed their journey down the river, arriving in Peterwardein on August 18, 1769. Liesganig had left his instruments and his assistant Rämspöck in Buda to wait for Verité. The two of them caught up with Liesganig in Peterwardein on August 24, and the team started on-ground measurements. Among the obstacles that slowed down his work, Liesganig mentioned the rainy weather and the scarcity of wood for preparing artificial signs to mark the triangulation network. He also hired a military guard for protection, although without providing further details about the reasons for this decision. But even during the work for the Cassini Map of France, peasants regarded the measurements of surveyors with suspicion, as possible precursors to an increase in taxation. ${ }^{22}$ After laying down the triangulation network and a second baseline, he finalized the astronomical measurements by October 29, 1769 .

Taking the time and effort to record his every step reveals Liesganig's belief that both the actual experiment and its codification mattered in equal measure. Similar to the leaders of other eighteenth century expeditions to measure arcs of meridian, such as those who undertook the French-Spanish journey to

\footnotetext{
$20 \quad$ HHStA StK, Vortrage, box 104, folder 3, 247-51.

21 Marie-Noëlle Bourguet, Christian Licoppe and H. Otto Sibum, eds., "Introduction," Instruments, Travel and Science: Itineraries of Precision from the Seventeenth to the Twentieth Century (London; New York: Routledge, 2002), 9-10.

22 Konvitz, Cartography in France, 14.
} 
Quito, he strived to execute, codify and demonstrate the accuracy of his scientific labor. ${ }^{23}$ Before making his measurements from the early 1760 os and 1769 available to a wider public, he had to convince his patrons in Vienna about the reliability of his work. The journal of the expedition partially fulfilled this need.

Additionally, Liesganig prepared a cartographic representation of his work. The map complemented the information included in his written report and showed the area between the rivers Tisa and Danube, where he constructed his triangulation network. ${ }^{24}$ The point where the structure known as the Roman entrenchment touched the bank of the Tisa represented the starting point for the measurements. This entrenchment connected the river Tisa with the Danube and served as an organizing line for Liesganig for his triangulation network. Point A on Figure 6.3 represents the inn of the village Czurock, transformed by the astronomers into a temporary observatory for which they calculated the latitude. The fragment also shows parts of some of the triangles' edges and the angles between them. In the end, Liesganig and his team measured a small segment of the Peterwardein meridian between the tower of the Peterwardein fortress and the parallel going through the inn in Czurock. Based on these measurements the Jesuit deducted the value of one degree of meridian in the Hungarian lowlands. He published his calculations and results in $1770 . .^{25}$

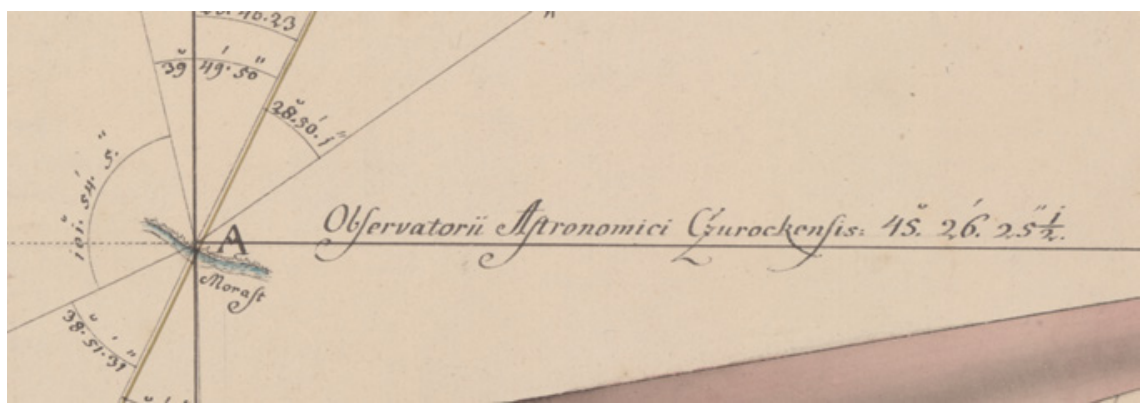

FIGURE 6.3 The village of Czurock's inn from Joseph Liesganig's “Carte von der bey Peterwardein zwischen der Donau, und Theiss befindlichen Römer Schanz" [Map of the Roman entrenchment located at Peterwardein between the Danube and Tisza] (1769) ÖSTERREICHISCHE NATIONALBIBLIOTHEK (ÖNB), KARTENSAMMLUNG, FKB C.89.2

25 Liesganig, Dimensio graduum meridiani Viennensis et Hungarici. 
Liesganig could not have finalized his measurements in just two months without the help of his assistants. In the final report the Jesuit praised the two engineers, Unterberger and Verité, for their hard work and their ability to do all mathematical calculations and to use instruments such as the quadrant. ${ }^{26}$ Liesganig's compliments suggest the two engineers already had a strong background in mathematics and the use of geodetic instruments as a result of their education in the Viennese schools.

As requested by the empress, in exchange for financial support to complete the measurement of the meridian arc in Hungary, Liesganig prepared a short description of a method to map large territories based on mathematical principles. ${ }^{27}$ From the opening paragraph, he denied any claims to originality and named the Academy of Sciences in Paris and their Map of France as inspirations for this methodology. Liesganig discussed all the steps necessary to survey a large territory, including creating a triangulation network and using trigonometric rules to calculate the sides and angles of triangles. He decried the lack of preparation of most military engineers with respect to theoretical geometry and criticized the surveying work they did to create representations of the Habsburg dominions, thus attacking the principles adopted by the general quartermaster's staff for the first military survey $(1763-87) \cdot{ }^{28}$ Nonetheless, Liesganig did not consider the work of military engineers pointless, and insisted that existing maps could be improved with the help of his method. The scientist praised the ability of properly trained engineers to build a triangulation network and brought as an example the high quality work that Unterberger and Verité performed in Hungary. In Liesganig's opinion, the real obstacle in the way of good mapmaking was both a lack of instruments, especially quadrants, and the absence of surveyors who could combine geodetic and astronomical measurements. ${ }^{29}$

As a preliminary step to creating a map for the monarchy, Liesganig suggested starting from the arcs of meridian he had measured in the early 1760 and in 1769 , and extending those triangulation networks north and south. He also recommended measuring another network from east to west along the fortyseventh parallel north, thus connecting the Principality of Moldavia and the Habsburg province of Transylvania at one end with the Swiss Cantons at the

26 HHStA StK, Vortrage, box 104, folder 3, 247-51.

27 Vienna, Kriegsarchiv (KA), Karten- und Plansammlung (KPS), K VII a 6-5.

28 For information about the first military survey see Madalina-Valeria Veres, "Putting Transylvania on the Map: Cartography and Enlightened Absolutism in the Habsburg Monarchy," Austrian History Yearbook 43 (2012): 141-64. 
other. Additionally, Liesganig wanted to compute two triangulation networks organized around two perpendiculars to the two meridians: one starting from Prague and covering Bohemia, the other going through Vienna and including Austria and Upper Hungary. In his opinion, a good engineer could calculate values for the two meridians and three perpendiculars in three years. At the end of his report, Liesganig volunteered to do a trial for a large territory in order to demonstrate the superiority of his method. ${ }^{30}$

On May 4, 1770, shortly after Liesganig submitted this project proposal, Maria Theresa ordered him to undertake a general survey of Lower Austria with the help of quadrants and triangles, employing his suggested methodology of astronomical measurements and a triangulation network. ${ }^{31}$ In midMay, he promised the conclusion of the survey by the fall of 1770 and asked for two thousand guldens to subsidize his travel and survey expenses. Liesganig claimed he required no assistants for the measurements. Nonetheless, he offered to train some military engineers during the survey of the surroundings of Vienna, as he had done during his 1769 work in Hungary. ${ }^{32}$ Similarly, in the early phases of his map of France, Cassini de Thury also trained engineers on the job in an area between Paris and Versailles, and he may have discussed this idea with Liesganig during his 1761 trip to Vienna. ${ }^{33}$ As a result of Liesganig's proposal, Kaunitz ordered the Aulic War Council to decide which engineers would work with Liesganig once the survey reached the surroundings of Vienna. ${ }^{34}$ The reports of Liesganig's survey of Lower Austria unfortunately appear to be missing. The last mention in the archives, dated June 28,1770 , documents Liesganig's decision to replace the on-the-job training of engineering students on how to conduct geometric survey operations with classroom instruction. ${ }^{35}$ It seems likely that Liesganig never finalized his survey of Lower Austria, and the general quartermaster's staff mapped this province as part of the first military survey operations. ${ }^{36}$

3o ka kps, K vii a $6-5$.

31 HHStA StK, Vortrage, box 105, folder 3, 12.

32 Ibid., 84-85.

33 François de Dainville, "Enseignement des 'Géographes' et des 'Géomètres', in Écoles techniques et militaires au XVIIIe siècle, ed. Roger Hahn and René Taton (Paris: Hermann, 1986): 481-91, here 488-89.

34 HHStA StK, Noten an den Hofkriegsrat, box 5, May 19, 1770.

35 KA Hofkriegsrat, Protocol 1037, Rubric 57, no. 73.

36 Lower Austria was surveyed by the general quartermaster's staff in the 1770 s under the command of Major von Neu. Josef Paldus, Die militärischen Aufnahmen im Bereiche der habsburgischen Länder aus der Zeit Kaiser Josephs II.: Ausgeführt durch den 
Liesganig remained valuable to the Habsburg rulers as an expert in the art of mapmaking even as the Jesuit order as a whole was dissolving. One year later, on August 9, 1771, an imperial order commissioned him to train a group of students from the Engineering Academy in Vienna in the science of astronomy. Prior to his arrival, officers from the engineering brigades had to prepare a select subgroup of students in the fields of theoretical geometry and trigonometry. The students had to possess a good grasp of surveying based on trigonometric operations. ${ }^{37}$ Clearly, the imperial leaders in Vienna engaged in the training of a new generation of mapmakers, experts in the fields of both geodetic and astronomical measurements.

\section{Conclusion}

In 1774, when asked for her opinion regarding the establishment of an Academy of Sciences in Vienna, Maria Theresa stated, "I could not possibly decide to set up an accademie des sciences [sic] with three ex-Jesuits and one professor of chemistry, however worthy; we should be a laughing-stock in the world."38 Liesganig's involvement in cartographic operations shows that the empress's declaration indicated neither intellectual apathy within her dominions nor contempt for the ex-Jesuits still present in her lands. Even as military engineers provided the manpower for on-ground surveying operations, scholars educated in the Jesuit tradition, and often members of this order, wrote theoretical treatises and trained some of the Habsburg officers on how to make maps.

A member of the Jesuit Austrian province, Liesganig served the Society as educator and scientist, especially in Vienna, but also in Hungary and later Galicia. Rather than a missionary, Liesganig served more as a Habsburg agent, consulting political rulers on scientific projects and fostering trans-imperial scientific exchanges with states such as France. Liesganig's activity in the 176os and the early 1770 s demonstrates the strong link between imperial priorities,

K.K. Generalquartiermeisterstab in den Jahren 1763-1785; Ein Beitrag zur historischen Landeskunde (Vienna: Alfred Hölder, 1919), 24.

37 Friedrich Gatti, Geschichte der K.u K. Ingenieur-und K.u K. Genie-Akademie, 1717-1869 (Vienna: W. Braumüller, 1901), 256; On August 25, 1771, the Genie and Fortification Corps sent the list of students: Götz Ioannes, Starck Franciscus, Appel Conradus, Mancini Salvator Emidius, Fuhrmann Carolus Antonius, Gemperlj Ernestus, Langer Carolus. KA GenieHauptamt, 17711538.

38 Robert J. W. Evans, "The Origins of Enlightenment in the Habsburg Lands," in Austria, Hungary, and the Habsburg. Essays on Central Europe, c. 1683-1867 (Oxford: Oxford University Press, 2006), 50. 
in this case mapmaking the Habsburg lands, and the contribution of members of the Jesuit order to the pursuit of scientific enterprises.

The collaboration with Cassini de Thury in 1761 and their successful mapping of the surroundings of Vienna most likely influenced Liesganig's commitment to implement a map of the Habsburg lands that would combine geodetic and astronomical measurements. In order to achieve this goal, the Jesuit convinced Maria Theresa to sponsor a scientific expedition to the Hungarian lowlands, where he measured one degree of meridian. Liesganig's work in Hungary not only contributed to the global debates about the shape of the Earth but also convinced the empress of his ability to coordinate small team of engineers away from the imperial capital.

Liesganig's determination to convince Maria Theresa of the need to connect geodetic and astronomical measurements for the mapping of the monarchy did not materialize, but his plea did not go unheard. Even as the general quartermaster's staff's engineers prioritized geodetic operations and disregarded astronomic observations, Maria Theresa continued to search for other scientific alternatives. Liesganig's 1769 memoir detailing a method to represent large territories on a map based on mathematical principles and Maria Theresa's decision to commission a general survey of Lower Austria based on the methodology of the Academy of Sciences in Paris reveal the resonance of his scientific ideas with the higher echelons of the Habsburg monarchy. 